\title{
NUTRITIVE VALUE AND FODDER POTENTIAL OF DIFFERENT SWEET SORGHUM GENOTYPES UNDER MEDITERRANEAN CONDITIONS
}

\author{
Ilker INAL ${ }^{1 *}$, Celal YUCEL ${ }^{2}$, Derya YUCEL ${ }^{2}$, Rustu HATIPOGLU ${ }^{3}$ \\ ${ }^{1}$ Eastern Mediterranean Agricultural Research Institute, Adana, TURKEY \\ ${ }^{2}$ Sirnak University, Faculty of Agriculture, Dept. of Field Crops, Sirnak, TURKEY \\ ${ }^{3}$ Cukurova University, Faculty of Agriculture, Dept. of Field Crops, Adana, TURKEY \\ *Corresponding author: ilker.inal@tarimorman.gov.tr
}

Received: 27.06.2020

\begin{abstract}
This study was conducted to determine biomass yields and feed quality parameters of 21 different sweet sorghums (Sorghum bicolor var. saccharatum (L.) Mohlenbr.) genotypes grown as the second crop after wheat harvest under Cukurova conditions. Field experiments were conducted at the experimental fields of Dogankent-Adana location of Eastern Mediterranean Agricultural Research Institute in randomized blocks design with 4 replications in the years 2016 and 2017 (June-October). According to the results of the variance analyses of tha data obtained from the experimenst, years, genotypes and year $\mathbf{x}$ genotype interactions had significant effects on investigated parameters. Averaged over two years, dry matter yield (DMY), days to $50 \%$ flowering, crude protein content, NDF, ADF, and RFV of the genotypes varied between 21.6 and $62.9 \mathrm{t} \mathrm{ha}^{-1}$, 55.0 and 99.1 days, 3.66 and $5.43 \%, 41.78$ and $52.42 \%, 29.14$ and $37.72 \%$, and 111.3 and 148 , respectively. It was determined that Ramada, Roma, Topper 76, UNL hybrid-3 and No91 genotypes were identified as late genotypes with DM yields of greater than $51 \mathrm{t} \mathrm{ha}^{-1}$; Ramada, Roma and Topper 76 genotypes had the first places in terms of quality and they were superior than the other standard cultivars and genotypes.
\end{abstract}

Keywords: Fodder yield, forage quality, genotype, sweet sorghum

\section{INTRODUCTION}

World population is now almost 7.8 billion people. Annual average increase in world population is $1.05 \%$ and world population is expected to reach 10.9 billion people by the end of 21st century (Cilluffo and Ruiz, 2019). Together with increasing population, food and energy needs are expected to increase 2-3 folds (Fedoroff et al., 2010; Palmgren et al., 2015). As in the world, Turkey has also limited land resources for agriculture and available agricultural lands are continuously depleting because of non-agricultural use of agricultural lands, excessive soil tillage practices and resultant soil loss and erosion, excessive irrigations and resultant salinity problems. Besides, water deficits still posing serious threats on agricultural practices generate serious problems in various parts of the world (Godfray et al., 2010). Recent climate change trends have negative impacts on agriculture. Especially extreme temperatures and severe droughts result in significant yield and quality losses in agricultural products. To mitigate yield losses under adverse climate and soil conditions, appropriate growing techniques and soil management practices should be used and the crops with abiotic stress-tolerance should be grown. Sweet sorghum has quite low fertilizer demand, is quite tolerant to high temperature, drought and salinity, less selective in soils, quite efficient in water use, thus it can be efficiently grown in arid and semi-arid regions. These characteristics make sorghum more advantageous over the other plant species under the same conditions (Mastrorilli et al., 1999; Gnansounou et al., 2005; Tesso et al., 2005). Although water demand of sorghum is less than the that of maize, sorghum has greater biomass potential than the other $\mathrm{C} 4$ crops (Gnansounou et al., 2005). Sweet sorghum is a short-day plant and has quite high temperature demand for optimum growth and development (Reise and Almodares, 2008). Sweet sorghum is a dedicated bioenergy crop, which has a higher biomass and forage yield potential than both forage sorghum and silage maize. Sweetness makes it highly palatable, thus it is highly preferred by livestock. Besides, biofuel generation from fodder crops is getting more popular in each day (Shanti et al., 2017). Insufficient supply of quality fodder is among the most important problems of Turkish livestock industry. To overcome this problem, production of summer grown $\mathrm{C} 4$ crops with a high biomass potential per unit area should be increased. Number of studies about potential use of sweet sorghum for forage production is highly limited in Turkey.

In this study, forage production potentials and some forage quality parameters of sweet sorghum genotypes 
grown as the second crop after wheat harvest under Mediterranean ecological conditions were investigated.

\section{MATERIALS AND METHODS}

\section{Experimental materials}

The names and source of the genotypes tested in this study were as follows: 1) Cowley, Dale, Grassi, M81-E, Mennonita, Nebraska sugarcane, PI579753, Ramada, Roma, Rox Orange, Smith, Sugar Drip, Theis, Topper 76, Tracy, UNL-Hybrid -3 ((26297xM81 E), Williams; 2) no:2 USDA-China, no91 USDA-Taiwan, no5 USDA South Africa; 3) Local check Gulseker. The mentioned plant material with the group numbers of 1, 2 and 3 were supplied by UNL (University of Nebraska, Lincoln, USA) and Western Mediterranean Agricultural Research Institute-Antalya/Turkey (supplied from ICRISAT and USDA gene bank) and University of Uludag, Bursa, Turkey, respectively.

\section{Soil and climate characteristics of the experimental site}

Experimental soils belong to Arikli soil series. Analyses on soil samples taken from 0-15 and 15-30 cm depths revealed that experimental soils were clay-loam (CL) in texture with $\mathrm{pH}$ values of between 7.0-7.50, total salt contents of between $0.22-0.27 \%, \mathrm{~N}$ contents of between $0.10-0.19 \%$, organic carbon (OC) contents of between $0.63-0.90 \%$, phosphorus $(\mathrm{P})$ contents of between $063-0.90 \mathrm{mg} \mathrm{kg}^{-1}$, lime $\left(\mathrm{CaCO}_{3}\right)$ contents of between 32.5 $35.0 \%$, sand contents of between $24-28 \%$, silt contents of between $41-43 \%$ and clay contents of between $30-33 \%$ (Yucel et al., 2018).

Throughout the experimental period (June-October), average temperature was $25.1^{\circ} \mathrm{C}$ in 2016 and $24.8^{\circ} \mathrm{C}$ in 2017; relative humidity was $79.0 \%$ in 2016 and $79.6 \%$ in 2017; total precipitation was calculated as $46.2 \mathrm{~kg} \mathrm{~m}^{2}$ in 2016 and $48.2 \mathrm{~kg} \mathrm{~m}^{2}$ in 2017. Since the precipitations were not sufficient to meet water demands, irrigations were performed as needed.

\section{Experimental design}

Experiments were conducted on the experimental fields of Eastern Mediterranean Agricultural Research Institute in Dogankent ( $36^{\circ} 51^{\prime} 35^{\prime \prime} \mathrm{N}$ and $35^{\circ} 20^{\prime} 43^{\prime \prime} \mathrm{E}$ ) in randomized blocks design with 4 replications during the years of 2016 and 2017. Sowing was performed in midJune after wheat harvest. Before sowing, $50 \mathrm{~kg} \mathrm{ha}^{-1}$ pure nitrogen and phosphorus were applied to the experimental plots as basal fertilizers. Genotypes were sown manually in 4 rows of $5 \mathrm{~m}$ long at $70 \mathrm{~cm}$ row spacing and $15 \mathrm{~cm}$ onrow plant spacing. Dressing fertilizers were applied manually when the plants reached to heights of $40-50 \mathrm{~cm}$ as to have $50 \mathrm{~kg} \mathrm{ha}^{-1}$ pure nitrogen and irrigations were initiated then. Harvests were performed at the beginning of dough stage. Side rows and $0.5 \mathrm{~m}$ top and bottom of the rows were omitted as to consider side effects. Then, plot yields and yield per hectare were determined. Harvest time changed depending on the genotypes, and it was completed in October in the first year and harvest of late genotypes was completed in the November in the second year because of prevailing precipitations.

\section{Sample preparation and chemical analyses}

During the harvest, 3 plants were randomly selected from each plot. Stalks were chopped into $15-20 \mathrm{~cm}$ long pieces and $1 \mathrm{~kg}$ fresh material was sampled. Samples were then dried in a drying chamber at $60^{\circ} \mathrm{C}$ for $7-10$ days until a constant mass. Dried samples were weighed to determine dry matter contents and dry matter yields. Dried samples were ground to pass 1-2 mm sieves. Kjeldahl method was used to determine nitrogen $(\mathrm{N})$ content of the samples.

Crude protein content was determined according to the following equation $(\mathrm{AOAC}, 1990) ; \mathrm{CP}$ content $=$ Nitrogen content (\%) x 6.25. (AOAC, 1990). Cell wall components (Neutral Detergen Fiber (NDF) and Acid Detergent Fiber (ADF) contents, \%) were determined with the aid of ANKOM fiber analyzer in accordance with the method specified by Van Soest et al. (1991). Digestible dry matter (DDM) content, dry matter intake (DMI) and relative feed value (RFV) were calculated with the equations provided by Schroeder (1994) as: $\mathrm{DDM}=88.9-(0.779 \mathrm{x} \% \mathrm{ADF})$; $\mathrm{DMI}=120 / \% \mathrm{NDF} ; \mathrm{RFV}=(\% \mathrm{DDM} X \% \mathrm{DMI}) / 1.29$.

Experimental data were analyzed using JMP statistical software in accordance with the randomized complete blocks design (RCBD). Significant means were compared with TUKEY's test at $\mathrm{P} \leq 0.05$ significance level (Steel at al., 1997).

\section{RESULTS AND DISCUSSION}

Days to $50 \%$ Flowering (day): Variance analysis revealed that genotype and genotype $\mathrm{x}$ year interactions had significant effects on days to $50 \%$ flowering. Days to $50 \%$ flowering was determined as 75.2 and 74.1 days in the first and second years of the study, respectively. Significant differences were observed in days to $50 \%$ flowering with the years (Table 1). However, effects of the years on days to $50 \%$ flowering varied with the genotypes. Thusly, P1579753, Ramada and Gulseker genotypes reached to $50 \%$ flowering in significantly shorter time in the second year than in the first year, but Smith and Williams genotypes reached to $50 \%$ flowering in significantly longer time in the second year than in the first year. As the average of two years, days to $50 \%$ flowering of the genotypes varied between $55.0-99.1$ days (Table 1). The Topper 76 genotype with 99.1 days reached to $50 \%$ flowering in significantly longer time than the other genotypes. Mennonita, Rox Orange and No2 genotypes reached to $50 \%$ flowering in significantly shorter time than the other genotypes. Shukla et al. (2017) classified sweet sorghum genotypes based on number of days to flowering as early (reaching to flowering in $\leq 70$ days), medium (reaching to flowering in between 70-83 days) and late (reaching to flowering in $\geq 83$ days). According to this classification, 11 of investigated 21 genotypes were identified as early, 3 as medium and 7 as late genotypes. In other studies, days to $50 \%$ flowering of sweet sorghum genotypes were reported as between 54.9- 
81.0 days (Mohammed and Mohamed, 2009; Mumtaz et al., 2019).

Table 1. Days to 50\% flowering and green dry matter yield of sweet sorghum genotypes

\begin{tabular}{|c|c|c|c|c|c|c|}
\hline \multirow[t]{2}{*}{ Genotypes } & \multicolumn{3}{|c|}{ Days to Flowering (Day) } & \multicolumn{3}{|c|}{ Dry Matter Yield $\left(\mathrm{t} \mathrm{ha}^{-1}\right)$} \\
\hline & 2016 & 2017 & Mean & 2016 & 2017 & Mean \\
\hline Cowley & $62.3 \mathrm{mno}^{1}$ & $66.0 \mathrm{j}-\mathrm{n}$ & $64.1 \mathrm{~g}^{*}$ & $39.4 \mathrm{f}-\mathrm{n}^{1}$ & $41.2 \mathrm{e}-\mathrm{m}$ & $40.3 \mathrm{~d}-\mathrm{h}$ \\
\hline Dale & $74.0 \mathrm{fgh}$ & $72.0 \mathrm{f}-1$ & $73.0 \mathrm{~d}$ & $33.4 \mathrm{~h}-\mathrm{n}$ & $35.3 \mathrm{~h}-\mathrm{n}$ & $34.3 \mathrm{f}-1$ \\
\hline Grassi & $71.8 \mathrm{f}-1$ & $76.0 \mathrm{f}$ & $73.9 \mathrm{~d}$ & $48.8 \mathrm{c}-\mathrm{h}$ & $41.1 \mathrm{e}-\mathrm{m}$ & $44.9 \mathrm{~b}-\mathrm{f}$ \\
\hline M81-E & $98.5 \mathrm{abc}$ & $95.5 \mathrm{bc}$ & $97.0 \mathrm{ab}$ & $60.8 \mathrm{bc}$ & $38.3 \mathrm{~g}-\mathrm{n}$ & $49.6 \mathrm{~b}-\mathrm{e}$ \\
\hline Mennonita & $56.5 \mathrm{pq}$ & $53.5 \mathrm{q}$ & $55.0 ~ h$ & 14.5 o & $28.7 \mathrm{j}-\mathrm{o}$ & 21.6 j \\
\hline N. sugarcane & $68.3 \mathrm{1jk}$ & $66.3 \mathrm{j}-\mathrm{m}$ & $67.3 \mathrm{e}-\mathrm{g}$ & $41.1 \mathrm{e}-\mathrm{m}$ & $38.2 \mathrm{~g}-\mathrm{n}$ & $39.6 \mathrm{e}-\mathrm{h}$ \\
\hline P1579753 & $68.8 \mathrm{ijk}$ & $61.0 \mathrm{n}-\mathrm{p}$ & $64.9 \mathrm{fg}$ & $28.2 \mathrm{k}-\mathrm{o}$ & $36.8 \mathrm{~h}-\mathrm{n}$ & $32.5 \mathrm{~g}-\mathrm{j}$ \\
\hline Ramada & $93.8 \mathrm{~cd}$ & $87.5 \mathrm{e}^{\mathrm{t}}$ & $90.6 \mathrm{c}$ & $57.3 \mathrm{~b}-\mathrm{f}$ & $48.0 \mathrm{c}-1$ & $52.6 \mathrm{a}-\mathrm{c}$ \\
\hline Roma & $90.0 \mathrm{de}$ & $87.8 \mathrm{e}$ & $88.9 \mathrm{c}$ & $61.5 \mathrm{a}-\mathrm{c}$ & $49.3 \mathrm{c}-\mathrm{h}$ & $55.4 \mathrm{ab}$ \\
\hline Rox Orange & $55.0 \mathrm{q}$ & $56.3 \mathrm{pq}$ & $55.6 \mathrm{~h}$ & $23.7 \mathrm{~m}-\mathrm{o}$ & 35.0 h-n & $29.3 \mathrm{~h}-\mathrm{j}$ \\
\hline Smith & $62.81-0$ & $75.0 \mathrm{fg}$ & $68.9 \mathrm{e}$ & $27.8 \mathrm{k}-\mathrm{o}$ & $56.0 \mathrm{~b}-\mathrm{g}$ & $41.9 \mathrm{c}-\mathrm{g}$ \\
\hline Sugar Drip & $64.3 \mathrm{k}-\mathrm{o}$ & $67.81-1$ & $66.0 \mathrm{efg}$ & $26.91-0$ & $31.2 \mathrm{~h}-\mathrm{o}$ & $29.0 \mathrm{~h}-\mathrm{j}$ \\
\hline Theis & $99.5 \mathrm{ab}$ & $95.3 \mathrm{bc}$ & $97.4 \mathrm{ab}$ & $59.4 \mathrm{~b}-\mathrm{d}$ & 40.6 e-n & $50.0 \mathrm{~b}-\mathrm{e}$ \\
\hline Topper 76 & 101.5 a & $96.8 \mathrm{a}-\mathrm{c}$ & 99.1 a & $57.7 \mathrm{~b}-\mathrm{e}$ & $45.2 \mathrm{c}-\mathrm{k}$ & $51.4 \mathrm{a}-\mathrm{d}$ \\
\hline Tracy & $67.81-1$ & $66.0 \mathrm{j}-\mathrm{n}$ & $66.9 \mathrm{e}-\mathrm{g}$ & $31.2 \mathrm{~h}-\mathrm{o}$ & 39.9 e-n & $35.6 \mathrm{f}-1$ \\
\hline UNL-Hyb-3 & $89.0 \mathrm{de}$ & $85.8 \mathrm{e}$ & $87.4 \mathrm{c}$ & 79.3 a & $46.6 \mathrm{c}-\mathrm{j}$ & $62.9 \mathrm{a}$ \\
\hline Williams & $60.5 \mathrm{op}$ & $67.81-1$ & $64.1 \mathrm{~g}$ & $26.71-0$ & $35.8 \mathrm{~h}-\mathrm{n}$ & $31.3 \mathrm{~g}-\mathrm{j}$ \\
\hline No2 & $56.5 \mathrm{pq}$ & $53.8 \mathrm{q}$ & $55.1 \mathrm{~h}$ & 22.5 no & 29.9 1-0 & $26.2 \mathrm{ij}$ \\
\hline No91 & $95.5 \mathrm{bc}$ & $96.0 \mathrm{bc}$ & $95.8 \mathrm{~b}$ & $69.0 \mathrm{ab}$ & $41.9 \mathrm{~d}-1$ & $55.5 \mathrm{ab}$ \\
\hline No5 & $67.31-\mathrm{m}$ & $69.0 \mathrm{~h}-\mathrm{k}$ & $68.1 \mathrm{ef}$ & $41.3 \mathrm{~d}-\mathrm{m}$ & $31.9 \mathrm{~h}-\mathrm{o}$ & $36.6 \mathrm{f}-1$ \\
\hline Gulseker & $76.0 \mathrm{f}$ & $70.0 \mathrm{~g}-\mathrm{j}$ & $73.0 \mathrm{~d}$ & $28.7 \mathrm{j}-\mathrm{o}$ & $31.8 \mathrm{~h}-\mathrm{o}$ & $30.3 \mathrm{~g}-\mathrm{j}$ \\
\hline Mean & 75.2 & 74.1 & & $41.9 \mathrm{~A}^{+}$ & $39.2 \mathrm{~B}$ & \\
\hline CV (\%) & & 2.45 & & & 15.80 & \\
\hline F Genotype (G) & & $* *$ & & & $* *$ & \\
\hline F Year $(\mathrm{Y})$ & & ÖD & & & $* *$ & \\
\hline F G x Y Int. & & $* *$ & & & $* *$ & \\
\hline
\end{tabular}

Dry Matter Yield (t ha $\left.\mathbf{~}^{-1}\right)$ : As the averaged value over the genotypes, dry matter yield was determined as 41.9 $\mathrm{t} / \mathrm{ha}$ in the first year and $39.2 \mathrm{t} \mathrm{ha}^{-1}$ in the second year. The averaged dry matter yield of the first year was significantly greater than that of the second year. However, year $\mathrm{x}$ genotype interactions had significant effects on dry matter yields, thus effects of years on dry matter yield varied with the genotypes. Thusly, Smith genotype had significantly greater dry matter yield in the second year than in the first year. On the other hand, M81E, Theis, UNL-Hyb-3 and No91 genotypes significantly lower dry matter yields in the second year than in the first year. Dry matter yields of the other genotypes did not vary significantly with the years. Since Smith genotype reached to $50 \%$ flowering in a longer time in the second year than the first year (Table 1), the genotype had longer time to produce dry matter, thus had greater dry matter yield in the second year. On the other hand, days to $50 \%$ flowering of M81-E, Theis, UNL-Hyb-3 and No 91 genotypes with significantly lower dry matter yields in the second year than the first year did not significantly vary with the years (Table 1). Low dry matter yields of the genotypes were mostly attributed to lower average temperatures of the second year than the first year throughout the growing season. As the average of two years, dry matter (DM) yields of the genotypes varied between $21.6-62.9 \mathrm{t} \mathrm{ha}^{-1}$ (Table 1) with the greatest dry matter yield from UNLHyb-3 genotype and the lowest dry matter yield from Mennonita genotype. The dry matter yields of Ramada, Roma, Topper 76 and No91 genotypes were not significantly different from that of UNL-Hyb-3 genotype. In previous studies conducted with different genotypes and under different ecologies, dry matter yields of sweet sorghum genotypes were reported as between $7.0-38.82 \mathrm{t}$ ha $^{-1}$ (Turgut et al., 2005; Ayub et al., 2012; Cavalaris et al., 2017; Shanti et al., 2017; Vinutha et al., 2017). Except for early genotypes, present dry matter yields were greater than the values reported in earlier studies. Such greater yields were attributed to advantageous soil and climate conditions of the present experimental site.

Crude Protein Content (\%): Year, genotype and year $x$ genotype interactions had significant effects on crude protein content of sweet sorghum (Table 2). As the averaged value over genotypes, significantly lower crude protein content (CPC) was observed in the first year of the experiments than the second year. Precipitations in October and lower average temperatures in the second year than in the first year retarded plant aging, thus mean 
CPC of the second year was significantly higher than the first year. Thusly, Kruse et al. (2008), Akar et al. (2014) and Ileri et al. (2018) also reported lower CPCs for maize plants in hotter years. Since year x genotype interactions had significant effects on CPCs, effects of the years on CPCs varied with the genotypes. Accordingly, Dale, M81E, Smith, Sugar Drip, Topper, Williams, No91 and No5 genotypes had significantly greater CPCs in the second year than in the first year, but years did not generate significant differences in CPCs of the other genotypes (Table 2). As the average of two years, crude protein contents of the genotypes varied between $2.59-6.63 \%$ and differences were found to be significant (Table 2). Rox Orange genotype $(5.43 \%)$ had significantly greater CPCs than Cowley, M81-E and Theis genotypes. On the other hand, Theis genotype $(3.66 \%)$ had significantly lower CPC than the other genotypes, except for Cowley, Dale, M81-E, Ramada, Topper, Tracy, UNL-Hyb-3 Williams and No5 genotypes. Mohammed and
Mohammed (2009) reported crude protein contents of sweet sorghum genotypes as between 6.6 - 11.0\%, Ayub at al. (2012) as between 6.62-8.29\%, Mahmood et al. (2013) as between $5.6-10.0 \%$, Neto et al. (2017) as between $6.11-11.71 \%$ and Shanti et al. (2017) as between $9.28-10.05 \%$. Aguiar et al. (2006) reported crude protein contents of sorghum above-ground biomass as between $4.2-13.3 \%$. CPCs determined in this study were lower than the values reported in previous studies. Such differences were mainly attributed to differences in genotypes, growing conditions, cultural practices, greater plant heights and yields of the present study. Leaf/stalk content decreases with increasing plant heights, stalks contain less crude protein than the leaves, thus greater plant height negatively influence CPCs. Accordingly, Dagtekin (2019) reported highly significant negative correlations between plant height and crude protein contento of pearl millet (Pennisetum glaucum).

Table 2. Crude protein content and neutral detergent fiber of sweet sorghum genotypes

\begin{tabular}{|c|c|c|c|c|c|c|}
\hline \multirow{2}{*}{ Genotypes } & \multicolumn{3}{|c|}{ Crude Protein Content (\%) } & \multicolumn{3}{|c|}{ Neutral Detergent Fiber (\%) } \\
\hline & 2016 & 2017 & Mean & 2016 & 2017 & Mean \\
\hline Cowley & $3.54 \mathrm{hk}^{1}$ & $4.68 \mathrm{c}-\mathrm{j}$ & $4.11 \mathrm{~cd}^{*}$ & $57.14 a-f^{1}$ & $41.11 \mathrm{ij}$ & $49.12 \mathrm{ab}^{*}$ \\
\hline Dale & $3.411-\mathrm{k}$ & $5.72 \mathrm{a}-\mathrm{g}$ & $4.56 \mathrm{a}-\mathrm{d}$ & $43.68 \mathrm{~h}-\mathrm{j}$ & $40.75 \mathrm{ij}$ & $42.22 \mathrm{~b}$ \\
\hline Grassi & $4.35 \mathrm{~d}-\mathrm{k}$ & $5.73 \mathrm{a}-\mathrm{g}$ & $5.05 \mathrm{a}-\mathrm{c}$ & $56.92 \mathrm{a}-\mathrm{g}$ & $44.24 \mathrm{f}-\mathrm{j}$ & $50.58 \mathrm{a}$ \\
\hline M81-E & $2.59 \mathrm{k}$ & $5.78 \mathrm{a}-\mathrm{g}$ & $4.18 \mathrm{~b}-\mathrm{d}$ & $57.59 \mathrm{a}-\mathrm{d}$ & $46.91 \mathrm{~d}-\mathrm{j}$ & $52.25 \mathrm{a}$ \\
\hline Mennonita & $4.74 b-1$ & $5.29 \mathrm{a}-\mathrm{h}$ & $5.02 \mathrm{a}-\mathrm{c}$ & $57.24 \mathrm{a}-\mathrm{e}$ & $35.80 \mathbf{j}$ & $46.52 \mathrm{ab}$ \\
\hline N. sugarcane & $4.70 c-j$ & $5.47 \mathrm{a}-\mathrm{g}$ & $5.08 \mathrm{a}-\mathrm{c}$ & $47.77 \mathrm{c}-\mathrm{j}$ & $42.36 \mathrm{~h}-\mathrm{j}$ & $45.06 \mathrm{ab}$ \\
\hline P1579753 & $4.48 \mathrm{~d}-\mathrm{j}$ & $5.31 \mathrm{a}-\mathrm{h}$ & $4.89 \mathrm{a}-\mathrm{c}$ & $60.46 \mathrm{ab}$ & $40.30 \mathrm{ij}$ & $50.38 \mathrm{a}$ \\
\hline Ramada & $4.25 \mathrm{e}-\mathrm{k}$ & $5.28 \mathrm{a}-\mathrm{h}$ & $4.77 \mathrm{a}-\mathrm{d}$ & $48.56 \mathrm{~b}-\mathrm{j}$ & $44.25 \mathrm{e}-\mathrm{j}$ & $46.41 \mathrm{ab}$ \\
\hline Roma & $4.29 \mathrm{~d}-\mathrm{k}$ & $6.07 \mathrm{a}-\mathrm{e}$ & $5.18 \mathrm{a}-\mathrm{c}$ & $52.40 \mathrm{a}-1$ & $41.00 \mathrm{1j}$ & $46.70 \mathrm{ab}$ \\
\hline Rox Orange & $5.02 \mathrm{a}-1$ & $5.85 \mathrm{a}-\mathrm{f}$ & $5.43 \mathrm{a}$ & $52.79 \mathrm{a}-1$ & $43.04 \mathrm{~h}-\mathrm{j}$ & $47.91 \mathrm{ab}$ \\
\hline Smith & 3.99 g-k & $6.63 \mathrm{a}$ & $5.31 \mathrm{ab}$ & $48.72 b-j$ & $44.09 \mathrm{~g}-\mathrm{j}$ & $46.41 \mathrm{ab}$ \\
\hline Sugar Drip & $3.54 \mathrm{~h}-\mathrm{k}$ & $6.41 \mathrm{a}-\mathrm{c}$ & $4.98 \mathrm{a}-\mathrm{c}$ & $54.97 \mathrm{a}-\mathrm{h}$ & $42.07 \mathrm{~h}-\mathrm{j}$ & $48.52 \mathrm{ab}$ \\
\hline Theis & $2.89 \mathrm{j}-\mathrm{k}$ & $4.27 \mathrm{~d}-\mathrm{j}$ & $3.66 \mathrm{~d}$ & $49.26 \mathrm{~b}-1$ & $47.66 \mathrm{~d}-\mathrm{j}$ & $48.46 \mathrm{ab}$ \\
\hline Topper 76 & $3.52 \mathrm{~h}-\mathrm{k}$ & $5.69 \mathrm{a}-\mathrm{g}$ & $4.60 \mathrm{a}-\mathrm{d}$ & $45.02 \mathrm{~d}-\mathrm{j}$ & $47.07 \mathrm{~d}-\mathrm{j}$ & $46.04 \mathrm{ab}$ \\
\hline Tracy & $3.54 \mathrm{~h}-\mathrm{k}$ & $5.02 \mathrm{a}-1$ & $4.28 \mathrm{a}-\mathrm{d}$ & $41.62 \mathrm{ij}$ & $41.94 \mathrm{ij}$ & $41.78 \mathrm{~b}$ \\
\hline UNL-Hyb-3 & $4.04 \mathrm{f}-\mathrm{k}$ & $4.79 b-1$ & $4.41 \mathrm{a}-\mathrm{d}$ & $52.13 \mathrm{a}-\mathrm{j}$ & $41.54 \mathrm{ij}$ & $46.84 \mathrm{ab}$ \\
\hline Williams & $3.53 \mathrm{~h}-\mathrm{k}$ & $6.05 \mathrm{a}-\mathrm{e}$ & $4.79 \mathrm{a}-\mathrm{d}$ & $49.24 \mathrm{~b}-\mathrm{j}$ & $41.61 \mathrm{ij}$ & $45.42 \mathrm{ab}$ \\
\hline No2 & $4.47 \mathrm{~d}-\mathrm{j}$ & $5.76 \mathrm{a}-\mathrm{g}$ & $5.12 \mathrm{a}-\mathrm{c}$ & $46.30 \mathrm{~d}-\mathrm{j}$ & $46.51 \mathrm{~d}-\mathrm{j}$ & $46.40 \mathrm{ab}$ \\
\hline No91 & $3.241-\mathrm{k}$ & $6.53 \mathrm{ab}$ & $4.89 a-c$ & $60.68 \mathrm{a}-\mathrm{c}$ & $43.72 \mathrm{~h}-\mathrm{j}$ & $52.20 \mathrm{a}$ \\
\hline No5 & $3.311-\mathrm{k}$ & $5.76 \mathrm{a}-\mathrm{g}$ & $4.53 \mathrm{a}-\mathrm{d}$ & $50.24 \mathrm{a}-1$ & $44.41 \mathrm{e}-\mathrm{j}$ & $47.33 \mathrm{ab}$ \\
\hline Gulseker & $4.43 \mathrm{~d}-\mathrm{j}$ & $6.11 \mathrm{a}-\mathrm{d}$ & $5.27 \mathrm{a}-\mathrm{c}$ & $62.47 \mathrm{a}$ & $42.37 \mathrm{~h}-\mathrm{j}$ & $52.42 \mathrm{a}$ \\
\hline Mean & $3.90 \mathrm{~B}$ & $5.64 \mathrm{~A}^{+}$ & & $52.15 \mathrm{~A}^{+}$ & 42.99 B & \\
\hline $\mathrm{CV}(\%)$ & & 13.49 & & & 9.62 & \\
\hline F Genotype (G) & & $* *$ & & & $* *$ & \\
\hline F Year (Y) & & $* *$ & & & $* *$ & \\
\hline F G x Y Int. & & $* *$ & & & $* *$ & \\
\hline
\end{tabular}

*)The means indicated with the same letter in the same column are not significantly different according to the Tukey test at $\mathrm{P} \leq 0.05$

+) The means indicated with the same capital letter in the same row are not significantly different at $\mathrm{P} \leq 0.05$

1) The means of different year-genotype combinations with the same lower case letters are not significantly different according to the Tukey test at $\mathrm{P} \leq 0.05$

Neutral Detergent Fiber (\%): Dry matter NDF contents of the genotypes were significantly influenced by the years, genotypes and year $\mathrm{x}$ genotype interactions. The averaged value of NDF content over the genotypes in the first year $(52.20 \%)$ was significantly higher than that in the second year (42.99) (Table 2). Again, precipitations in October of the second year and resultant cool temperatures retarded plant aging, thus reduced NDF content of dry matter as compared to the first year. Thusly, Lee et al. (2017) reported that grass species grown 
in cool regions had $21 \%$ less NDF content than in hot regions. Since the year $x$ genotype interactions had significant effects on NDF contents, effects of years on NDF contents varied with the genotypes. Accordingly, Gulseker, No91, P1579753, M 81-E, Mennonita, and Cowley, genotypes had significantly greater NDF contents in the first year than in the second year while years did not generate significant differences in NDF contents of the other genotypes. As the average of two years, NDF contents of the genotypes varied between $41.78-52.42 \%$ and differences were found to be significant. Gulseker, M81-E, No91, Grassi and P1579753 genotypes had significantly greater NDF contents than Dale and Tracy genotypes. In previous studies, NDF contents of sweet sorghum genotypes were reported as between 32.6 62.5\% (Mohammed and Mohamed, 2009; Machado et al., 2012; Neto et al., 2017; Vinutha et al., 2017). Our findings were in the range of values given in the mentioned reports.

Acid Detergent Fiber (\%): The ADF content of sweet sorghum dry matter was significantly influenced by the years, genotypes and year $\mathrm{x}$ genotype interactions. As it was in NDF contents, significantly higher averaged value of $\mathrm{ADF}$ content was determined in the first year than that in the second year (Table 3). NDF is cell membrane component and also includes ADF (Schroeder, 1994; Lema et al., 2000). Therefore, ADF content of dry matter increases with increasing NDF content. The effect of years on NDF content varied with the genotypes. Thusly, Cowley, M81-E, Mennonita, P1579753, no91 and Gulseker genotypes had significantly greater ADF contents in the first year than in the second year, but years did not generate significant differences in ADF content of the other genotypes (Table 3). As the average of two years, ADF contents of the genotypes varied between 29.14 - $37.72 \%$ and differences were found to be significant. Gulseker genotype $(37.72 \%)$ had significantly greater ADF content than Dale, Mennonita, N sugarcane, Ramada, Smith, Topper 76, Tracy, Williams, No2 and No5 genotypes. M81-E genotype had significantly greater ADF content than Tracy and Williams genotypes. In previous studies, ADF contents of sweet sorghum genotypes were reported as between 26.0 - 54.2\% (Lema et al., 2000; Madibela et al., 2002; Mohammed and Mohamed, 2009; Mahmood et al., 2013; Vinutha et al., 2017). Present ADF contents were again in range of values given in the mentioned earlier reports.

Table 3. Acid detergent fiber and relative feed value of sweet sorghum genotypes

\begin{tabular}{|c|c|c|c|c|c|c|}
\hline \multirow{2}{*}{ Genotypes } & \multicolumn{3}{|c|}{ Acid Detergent Fiber $(\%)$} & \multicolumn{3}{|c|}{ Relative Feed Value } \\
\hline & 2016 & 2017 & Mean & 2016 & 2017 & Mean \\
\hline Cowley & $38.97 \mathrm{a}-\mathrm{e}^{1}$ & $25.96 \mathrm{ij}$ & $32.46 \mathrm{a}-\mathrm{c}^{*}$ & $96.50 \mathrm{~g}-1^{1}$ & $157.2 \mathrm{ab}$ & $126.9 \mathrm{a}-\mathrm{c}^{*}$ \\
\hline Dale & $30.10 \mathrm{c}-\mathrm{j}$ & $29.59 \mathrm{e}-\mathrm{j}$ & $29.84 \mathrm{bc}$ & $141.6 \mathrm{~b}-\mathrm{f}$ & $150.4 \mathrm{a}-\mathrm{d}$ & $146.0 \mathrm{ab}$ \\
\hline Grassi & $36.63 \mathrm{a}-\mathrm{g}$ & $30.41 \mathrm{c}-\mathrm{j}$ & $33.52 \mathrm{a}-\mathrm{c}$ & $103.5 \mathrm{e}-1$ & $137.4 \mathrm{~b}-\mathrm{g}$ & $120.4 \mathrm{bc}$ \\
\hline M81-E & $39.57 \mathrm{a}-\mathrm{c}$ & $31.35 \mathrm{c}-\mathrm{j}$ & $35.46 \mathrm{ab}$ & $94.41-1$ & $128.3 \mathrm{~b}-\mathrm{j}$ & $111.3 \mathrm{c}$ \\
\hline Mennonita & 39.15 a-e & $22.78 \mathrm{j}$ & $30.96 \mathrm{bc}$ & $95.1 \mathrm{~h}-1$ & $188.1 \mathrm{a}$ & $141.6 \mathrm{ab}$ \\
\hline N. sugarcane & $31.42 \mathrm{c}-\mathrm{j}$ & $31.07 \mathrm{c}-\mathrm{j}$ & $31.25 \mathrm{bc}$ & $130.0 \mathrm{~b}-\mathrm{j}$ & $143.1 \mathrm{~b}-\mathrm{e}$ & $136.5 \mathrm{a}-\mathrm{c}$ \\
\hline P1579753 & $41.02 \mathrm{ab}$ & $26.84 \mathrm{~h}-\mathrm{j}$ & $33.96 \mathrm{a}-\mathrm{c}$ & $88.2 \mathrm{kl}$ & $157.9 \mathrm{ab}$ & $123.1 \mathrm{a}-\mathrm{c}$ \\
\hline Ramada & $30.35 \mathrm{c}-\mathrm{j}$ & $30.34 \mathrm{c}-\mathrm{j}$ & $30.34 \mathrm{bc}$ & $125.5 \mathrm{~b}-\mathrm{k}$ & $137.7 \mathrm{~b}-\mathrm{g}$ & $131.6 \mathrm{a}-\mathrm{c}$ \\
\hline Roma & $35.48 \mathrm{a}-1$ & $28.22 \mathrm{f}-\mathrm{j}$ & $31.85 \mathrm{a}-\mathrm{c}$ & $109.6 \mathrm{~d}-1$ & $151.9 \mathrm{a}-\mathrm{c}$ & $130.8 \mathrm{a}-\mathrm{c}$ \\
\hline Rox Orange & $35.70 \mathrm{a}-1$ & $29.10 \mathrm{f}-\mathrm{j}$ & $32.35 \mathrm{a}-\mathrm{c}$ & $107.9 \mathrm{c}-1$ & $144.7 \mathrm{~b}-\mathrm{e}$ & $126.3 \mathrm{a}-\mathrm{c}$ \\
\hline Smith & $34.55 \mathrm{a}-1$ & $28.52 \mathrm{f}-\mathrm{j}$ & $31.54 \mathrm{bc}$ & $118.5 \mathrm{~b}-1$ & $141.4 \mathrm{~b}-\mathrm{f}$ & $130.0 \mathrm{a}-\mathrm{c}$ \\
\hline Sugar Drip & $37.47 \mathrm{a}-\mathrm{f}$ & $29.36 \mathrm{f}-\mathrm{j}$ & $33.41 \mathrm{a}-\mathrm{c}$ & $101.2 \mathrm{f}-1$ & $146.2 \mathrm{~b}-\mathrm{d}$ & $123.7 \mathrm{a}-\mathrm{c}$ \\
\hline Theis & $35.24 \mathrm{a}-1$ & $32.30 \mathrm{~b}-\mathrm{j}$ & $33.77 \mathrm{a}-\mathrm{c}$ & $116.3 \mathrm{~b}-1$ & $124.5 \mathrm{~b}-\mathrm{k}$ & $120.4 \mathrm{bc}$ \\
\hline Topper 76 & $29.91 \mathrm{~d}-\mathrm{j}$ & $29.09 \mathrm{f}-\mathrm{j}$ & $29.50 \mathrm{bc}$ & $136.3 \mathrm{~b}-\mathrm{h}$ & $131.2 \mathrm{~b}-\mathrm{j}$ & $133.8 \mathrm{a}-\mathrm{c}$ \\
\hline Tracy & $29.90 \mathrm{e}-\mathrm{j}$ & $28.38 \mathrm{f}-\mathrm{j}$ & 29.14 c & $146.9 \mathrm{a}-\mathrm{d}$ & $149.3 \mathrm{a}-\mathrm{d}$ & 148.1 a \\
\hline UNL-Hyb-3 & $36.05 \mathrm{a}-\mathrm{h}$ & $31.67 \mathrm{c}-\mathrm{j}$ & $33.86 \mathrm{a}-\mathrm{c}$ & $108.8 \mathrm{~d}-1$ & $144.6 \mathrm{~b}-\mathrm{e}$ & $126.7 \mathrm{a}-\mathrm{c}$ \\
\hline Williams & $31.11 \mathrm{c}-\mathrm{j}$ & $27.26 \mathrm{~g}-\mathrm{j}$ & $29.18 \mathrm{c}$ & $124.7 \mathrm{~b}-\mathrm{k}$ & $151.5 \mathrm{a}-\mathrm{c}$ & $138.1 \mathrm{a}-\mathrm{c}$ \\
\hline No2 & $30.58 \mathrm{c}-\mathrm{j}$ & $29.21 \mathrm{f}-\mathrm{j}$ & $29.90 \mathrm{bc}$ & $132.2 \mathrm{~b}-\mathrm{h}$ & 134.4 b-1 & $133.3 \mathrm{a}-\mathrm{c}$ \\
\hline No91 & $39.50 \mathrm{a}-\mathrm{d}$ & $30.96 \mathrm{c}-\mathrm{j}$ & $35.23 \mathrm{a}-\mathrm{c}$ & 90.2 j-1 & $138.0 \mathrm{~b}-\mathrm{g}$ & $114.1 \mathrm{c}$ \\
\hline No5 & 33.14 b-1 & $27.38 \mathrm{~g}-1$ & $30.26 \mathrm{bc}$ & $118.1 \mathrm{~b}-1$ & $142.6 \mathrm{~b}-\mathrm{f}$ & $130.3 \mathrm{a}-\mathrm{c}$ \\
\hline Gulseker & $43.94 \mathrm{a}$ & $31.51 \mathrm{c}-\mathrm{j}$ & 37.72 a & 81.51 & $141.6 \mathrm{~b}-\mathrm{f}$ & $111.6 \mathrm{c}$ \\
\hline Mean & $35.23 \mathrm{~A}$ & $29.11 \mathrm{~B}^{+}$ & & 112.7 B & $144.9 \mathrm{~A}^{+}$ & \\
\hline $\mathrm{CV}(\%)$ & & 10.50 & & & 11.42 & \\
\hline F Genotype (G) & & $* *$ & & & $* *$ & \\
\hline F Year $(Y)$ & & $* *$ & & & $* *$ & \\
\hline F G x Y Int. & & $* *$ & & & $* *$ & \\
\hline
\end{tabular}

*)The means indicated with the same letter in the same column are not significantly different according to the Tukey test at $\mathrm{P} \leq 0.05$

+) The means indicated with the same capital letter in the same row are not significantly different at $\mathrm{P} \leq 0.05$

1) The means of different year-genotype combinations with the same lower case letters are not significantly different according to the Tukey test at $\mathrm{P} \leq 0.05$ 
Relative Feed Value: Relative feed value (RFV) of the sweet sorghum genotypes were significantly influenced by the years, genotypes and year $\mathrm{x}$ genotype interactions. Averaged value of RFV (144.9) in the second year was significantly higher than that in the first year (112.7) (Table 5). RFV is closely related to DDM and DMI (Linn and Martin, 1999). Effects of the years on RFV of genotypes varied with the genotypes (Table 3). Accordingly, Cowley, Mennonita, P1579753, Roma, Sugar Drip, No91 and Gulseker genotypes had significantly greater RFVs in the second year than in the first year, but RFVs of the other genotypes did not vary significantly with the years (Table 3 ). As the average of two years, RFVs of the sorghum genotypes varied between $111.3-148.1$ and differences were found to be significant. Tracy genotype had significantly greater RFV than Grassi, M81-E, Theis, No91 and Gulseker genotypes, but the other genotypes did not significantly different from each other in RFV. Also, Dale and Mennonita genotypes had greater RFV than M81-E, No91 and Gulseker genotypes. RFV is used as an indicator of feed quality and assumed to be 100 for alfalfa hay at flowering stage. (Moore and Undersander, 2002; Hackmann et al.,2008). RFVs determined in this study were all greater than 100. At1s et al. (2012) reported RFVs of sorghum genotypes harvested at different development stages of plants as between 85.2 - 129.2.

\section{CONCLUSION}

In this study, field experiments were conducted with 21 different sweet sorghum genotypes grown as the second crop after wheat harvest under Eastern Mediterranean (Adana) ecological conditions for two years. Dry matter (DM) yields varied between 21.6 - 62.9 t/ha. Ramada, Roma, Topper 76, UNL hybrid-3 and No91 genotypes were identified as late genotypes with DM yields of greater than $51 \mathrm{t} / \mathrm{ha}$; Ramada, Roma and Topper 76 genotypes had the first places in terms of quality and they were superior than the other standard cultivars and genotypes. Sweet sorghum yields were 4-5 times greater than yields of silage maize grown as second crop under Cukurova conditions (Korkmaz et al., 2005; Yucel et al., 2005) and feed quality values were equivalent or greater than silage maize. From the results of this study, it was concluded that sweet sorghum with greater tolerance to drought and high temperatures, less fertilizer needs and selectivity in soils than maize could reliably be used as an alternative of silage maize to meet roughage deficits of livestock industry.

\section{ACKNOWLEDGEMENTS}

The authors thanks to TUBITAK for the financial support provided for the project (1140945) from which some data and materials were obtained.

\section{LITERATURE CITED}

Aguiar, E. M. De., G. F. da C. Lima, M. V. F. dos Santos, F. F. R. de Carvalho, A. Guim, H. R. de Medeiros and A. Q. Borges. 2006. Yield and chemical composition of chopped tropical grass hays. Rev. Bras. Zootec. 35 (6): 2226-2233.
Akar, T., M. Kaplan, N. Sagir and A. Gelebur. 2014. Effects of different liquid-manure treatments on yield and quality parameters of second-crop silage corn under reduced tillage conditions. Rom. Agric. Res. 31: 1-11.

AOAC. 1990. Association of Official Analytical Chemists. Official method of analysis. 15th ed. Washington, DC. USA, 66-88.

Atis, I., O. Konuskan, M. Duru, H. Gozubenli and S. Yilmaz, 2012. Effect of harvesting time on yield, composition and forage quality of some forage sorghum cultivars. Int. J. Agric. Biol. 14:879-886.

Ayub, M., M. Khalid, M. Tariq, M. Elahi and M. A. Nadeem. 2012. Comparison of sorghum genotypes for forage production and quality. J. Anim. Plant. Sci. 22(3):733-737.

Cavalaris, C., O. Merkouris, C. Karamoutis, S. Akdemir, D. Mamma, D. Kekos and T. Gemtos. 2017. Effects of row spacing on growth, yield and quality parameters of sweet sorghum. J Agr. Fac. Gaziosmanpasa Uni. 34 (1): 229-237. doi:10.13002/jafag4215.

Cilluffo, A. and , N.G. Ruiz. 2019. World populastion projected to nearly stop growing by the end of the century, https: Ilpewrsr.ch $\backslash z W z N H f$

Dagtekin, Z. 2019. Research on the adaptation of some annual warm season grass species to the Cukurova Conditions. MSc thesis, Department of Field Crops ,Institute of Natural and Appllied Sciences, Cukurova University, $141 \mathrm{~s}$ (in Turkish).

Fedoroff, N.V., D.S. Battisti, R.N. Beachy, P.J.M. Cooper, D.A. Fischhoff and C.N. Hodges. 2010. Radically rethinking agriculture for the 21st century. Sci. 327:833-4.

Gnansounou, E., A. Dauriat and C.E. Wyman. 2005. Refining sweet sorghum to ethanol and sugar: economic trade-offs in the context of North China. Bioresour Technol. 96: 9851002 .

Godfray, H.C.J., J.R. Beddington, I.R. Crute, L. Haddad, D, Lawrence and J.F. Muir. 2010. Food security: The challenge of feeding 9 billion people. Sci. 327:812-8.

Hackmann, T.J., J.D. Sampson and J.N. Spain. 2008. Comparing relative feed value with degradation parameters of grass and legume forages. J. Anim. Sci. 86: 2344-2356.

Ileri, O., E.B. Carpici, B. Erbeyi, A. Suleyman and K. Ali. 2018. Effect of sowing methods on silage yield and quality of some corn cultivars grown in second crop season under irrigated condition of central anatolia, turkey. Turk. J. Field Crops. 23: 72-79.

Korkmaz, Y., S. Aykanat, H. Yucel, M. Avci, C. Yucel and R. Hatipoglu. 2015. A research on yield and silage quality of silage corn (Zea mays L.) cultivars as second crop in Cukurova Condition. TAGEM (Agricultural Research and Policy General Directorate ) Final Project Report (in Turkish)

Kruse, S., A. Herrmann, A. Kornher and T. Friedhelm. 2008. Evaluation of genotype and environmental variation in fibre content of silage maize using a model-assisted approach. Eur. J. Agron. 28 (3): 210-223.

Lee, M.A., A.P. Davis, M.G.G. Chagunda and P. Manning. 2017. Forage quality declines with rising temperatures, with implications for livestock production and methane emissions. Biogeosciences 14: 1403-1417.

Lema, M., A. Felix, S. Salako and U. Bishnoi. 2000. Nutrient content and in vitro dry matter digestibility of silages made from various grain sorghum and sweet sorghum cultivars. J. Sust. Agr. 17(1): 55-70. DOI: 10.1300/J064v17n01_06.

Machado, L.C., W.M. Ferreira and C. Scpinello. 2012. Apparent digestibility of simplified and semi-simplified diets, with and without addition of enzymes, and nutritional value of fibrous sources for rabbits. Rev. Bras. Zootec. 41(7):1662-1670 
Madibela, O.R., W.S. Boitumelo, C. Manthe and I. Raditedu. 2002. Chemical composition and in vitro dry matter digestibility of twelve local landraces of sweet sorghum in Botswana. Livestock Res. Rural. Dev. 14(4): http://www.lrrd.org/lrrd14/4/madi144.htm.

Mahmood, A., H. Ullah, M. Ijaz, M.M. Javaid, A.N. Shahzad and B. Honermeier. 2013. Evaluation of sorghum hybrids for biomass and biogas production. Aust. J. Crop Sci. 7(10):1456-1462.

Mastrorilli, M., N. Katerji and G. Rana. 1999. Productivity and water use efficiency of sweet sorghum as affected by soil water deficit occurring at different vegetative growth stages. Eur. J. Agron. 11: 207-215.

Mohammed, M. and M. A. Mohamed. 2009. Evaluation of newly developed sweet sorghum (Sorghum bicolor) genotypes for some forage attributes. American-Eurasian J. Agric. Environ. Sci. 6 (4): 434-440.

Moore, J.E. and D.J. Undersander. 2002. Relative forage quality: an alternative to relative feed value and quality index. In: Proceedings 13th Annual Florida Ruminant Nutrition Symposium, pp: 16-32, Florida, USA

Mumtaz, A., D. Hussain, M. Saeed, M. Arshad and M.I. Yousaf. 2019. Stability and adaptability of sorghum hybrids elucidated with genotype-environment interaction biplots. Turk J. Field Crops. 24(2):155-163. DOI: 10.17557/tjfc.631130.

Neto, A.B., R.H. Pereira dos Reis, L.S. Cabral, J.G. Abreu, D.P. Sousa and F.G. Sousa. 2017. Nutritional value of sorghum silage of different purposes. Ciênc. Agrotec. 41(3):288-299. http://dx.doi.org/10.1590/1413-70542017413038516.

Palmgren, M.G., A.K. Edenbrandt, S.E. Vedel, M.M. Andersen, X. Landes and J.T. Østerberg. 2015. Are we ready for backto-nature crop breeding? Trends Plant Sci. 20: 155-64.

Reisi, F. and A. Almodares. 2008. The effect of planting date on amylose content in sorghum and corn". In: Proceeding of the 3rd Int. Biol. conference (Eds. F Reisi \& A Almodares). Tehran, Iran.

Schroeder, J.W. 1994. Interpreting forage Analysis. Extention Dairy specialist (NDSU). AS-1080, North Dakota State University.
Shanti, M., R. Susheela, A.V. Umakanth, M. Anuradha and T. Shashikala. 2017. Evaluation of sweet sorghum genotypes for fodder yield and quality under different levels of NPK. Forage Res. 42 (4):238-242.

Shukla, S., T.J. Felderhoff, A. Saballos and W. Vermerris. 2017. The relationship between plant height and sugar accumulation in the stems of sweet sorghum (Sorghum bicolor (L.) Moench). Field Crop. Res. 203:181-191.

Tesso, T.T., L.E. Claflin and M.R. Tuinstra. 2005. Analysis of stalk rot resistance and genetic diversity among drought tolerant sorghum genotypes. Crop Sci. 45: 645-652.

Turgut, I., U. Bilgili, A. Duman and E. Acikgoz. 2005. Production of sweet sorghum (Sorghum bicolor L. Moench) increases with increased plant densities and nitrogen fertilizer levels. Acta. Agr. Scand. 55 (3):236-240.

Steel, R.G.D., Torrie, J.H. and Dicky, D.A. (1997) Principles and Procedures of Statistics, A Biometrical Approach. 3rd Edition, McGraw Hill, Inc. Book Co., New York, 352-358.

Van Soest, P.J., J.D. Robertson and B.A. Lewis. 1991. Methods for dietary fibre, neutral detergent fibre and non-starch polysaccharides in relation to animal nutrition. J. Dairy Sci. 74: 3583-3597.

Vinutha, K.S., G.S. Anil Kumar, M. Blummel and P.S. Rao. 2017. Evaluation of yield and forage quality in main and ratoon crops of different sorghum lines. Trop. GrasslForrajes. 5(1):40-49. DOI: 10.17138/TGFT(5)40-49.

Yucel, C., R. Hatipoglu, I. Dweikat, I. Inal, F. Gundel, and H. Yucel. 2018. A Research on determination of biyo-etanol production potential of different sweet sorghum (Sorghum bicolor var. saccharatum (L.) Mohlenbr.) Genotypes in Cukurova and GAP regions. TUBITAK 1003 Project Final Report (Abstract in English), p.293.

Yucel, C., M. Avci, I. Inal and M.R. Akkaya. 2005. Effects of different mixing ratios and cutting time of some annual legume and cereal forage crops on silage quality in Cukurova conditions. TAGEM (Agricultural Research and Policy General Directorate) Final Project Report (in Turkish). 